\title{
Antioxidant Effects of Quinoline Alkaloids and 2,4-Di-tert-butylphenol Isolated from Scolopendra subspinipes
}

\author{
Mi-Ae Yoon, ${ }^{a, c}$ Tae-Sook Jeong, ${ }^{b}$ Doo-Sang Park, ${ }^{a}$ Ming-Zhe Xu, ${ }^{a}$ Hyun-Woo OH, ${ }^{a}$ \\ Kyoung-Bin Song, ${ }^{c}$ Woo Song LeE, ${ }^{*}, b$ and Ho-Yong PARK ${ }^{*, a}$ \\ ${ }^{a}$ Insect Resources Laboratory, Korea Research Institute of Bioscience and Biotechnology; ${ }^{b}$ National Research Laboratory \\ of Lipid Metabolism \& Atherosclerosis, Korea Research Institute of Bioscience and Biotechnology; Daejeon 305-333, \\ Korea: and ${ }^{c}$ Department of Food Science \& Technology, Chungnam National University; Daejeon 305-335, Korea. \\ Received September 28, 2005; accepted December 2, 2005
}

The oxidized low-density lipoprotein (ox-LDL) plays a critical role at the early stages of atherosclerosis. Thus, the prevention of LDL-oxidation by antioxidants may arrest the progression of atherosclerosis. Two quinoline alkaloids, 3,8-dihydroxyquinoline (1) and 2,8-dihydroxy-3,4-dimethoxyquinoline (3), and 2,4-di-tertbutylphenol (2) were isolated from the dried body of Scolopendra subspinipes. Compounds $1-3$ exhibited antioxidant activities on copper-mediated $\left(1: \mathrm{IC}_{50}=2.6 \mu \mathrm{M}, 2: \mathrm{IC}_{50}=8.2 \mu \mathrm{M}, 3: \mathrm{IC}_{50}=63.0 \mu \mathrm{M}\right)$, AAPH-mediated oxidation $\left(1: \mathrm{IC}_{50}=3.9 \mu_{\mathrm{M}}, 2: \mathrm{IC}_{50}=9.9 \mu_{\mathrm{M}}, 3: \mathrm{IC}_{50}=71.8 \mu \mathrm{M}\right)$, and SIN-1-mediated oxidation $(1: 70 \%, 2: 52 \%, 3: 29 \%$ at $5.0 \mu \mathrm{M})$ in the TBARS assay. The antioxidant activities of compounds $1-3$ were tested with respect to other parameters, such as the lag time of conjugated diene fromation, relative electrophoretic mobility (REM) of oxLDL, and apoB-100 fragmentation on copper-mediated LDL-oxidation. In addition, compounds $1-3$ showed 1,1-diphenyl-2-picrylhydrasyl (DPPH) radical scavenging activity and compound 1 also exhibited metal chelating activity. phenol

Key words Scolopendra subspinipes; low-density lipoprotein (LDL); antioxidant; 3,8-dihydroxyquinoline; 2,4-di-tert-butyl-

The centipede, Scolopendra subspinipes mutilans L. KocH (Scolopendridae), has been utilized as a traditional Chinese and Korean medicine for a variety of diseases, such as spasm, childhood convulsions, seizures, poisonous nodules, diphtheria, and tetanus. ${ }^{1,2)}$ Moon et al. reported that Jineol (1), isolated from the $S$. subspinipes, showed modest cytotoxic activity in vitro against the growth of various human tumor cell lines. ${ }^{3)}$ Thereafter, Centipedin, isolated from $S$. subspinipes, was found to exhibit the most significant antibiotic activity against gram-negative Klebsiella pneumoniae ATCC 8308 which is responsible for lung and intestine infections. ${ }^{4)}$ Also, Noda et al. described a group of novel quinoline alkaloids, the scolopendrines, with a 7-benzyl group that were isolated from $S$. subspinipes, however, they did not report on their biological activities. ${ }^{5)}$

In the course of searching for biological substances against low-density lipoprotein (LDL)-oxidation, acyl-CoA: cholesterol acyltransferase (ACAT), and lipoprotein-associated phospholipase $\mathrm{A}_{2}$ (Lp-PLA $\mathrm{A}_{2}$ ) from insect resources, methanol extracts of $S$. subspinipes showed significantly potent antioxidant activity against LDL-oxidation. ${ }^{6}$ During the last decade, it has been determined that ox-LDL contributes to the development of atherosclerosis by several mechanisms. ${ }^{7,8)}$ Oxidative modification of plasma LDL enhances its atherogenic potency and promotes its accumulation in monocyte-macrophages in the vascular wall, which lead to vascular lipidosis at the early stages of atherosclerosis. ${ }^{9}$ ) Thus, the prevention of LDL-oxidation by antioxidants may arrest the progression of atherosclerosis. Many antioxidants have been developed to exhibit the anti-atherogenic activities by inhibiting foam cell formation in an animal model. ${ }^{10)}$ Several antioxidants such as probucol, $N, N^{\prime}$-diphenylphenylenediamine, and butylated hydroxytoluene (BHT) have been shown to decrease the degree of LDL-oxidation and the extent of atheromatous lesions in animal models of atheroscle- rosis, but they had various side effects. ${ }^{11)}$

Subsequently, activity-guided fractionation of the methanol extracts led to the isolation of two quinoline alkaloids, 3,8-dihydroxyquinoline (1) and 2,8-dihydroxy-3,4dimethoxyquinoline (3), as well as 2,4-di-tert-butylphenol (2). In this study, we describe the isolation and antioxidant activities against LDL-oxidation of the compounds $1-\mathbf{3}$ (Fig. 1).

\section{MATERIALS AND METHODS}

General Experimental Methods The IR spectra were taken on a FT-IR spectrometer MB-100 (Bomen Co.) instrument with $\mathrm{KBr}$ pellets. ${ }^{1} \mathrm{H}-,{ }^{13} \mathrm{C}$-, and $2 \mathrm{D}-\mathrm{NMR}\left({ }^{1} \mathrm{H}-{ }^{1} \mathrm{H}\right.$ COSY, HMBC, and HMQC) spectra were recorded on a Bruker AM 500 FT-NMR [FT $500 \mathrm{MHz}$ NMR spectrometer AMX-500 (Bruker Co.)] with $\mathrm{CD}_{3} \mathrm{OD}$. HR-EI-MS was recorded on a JMS-700 (Jeol, Japan). Silica gel (230-400 mesh) and Lichroprep RP-18 $(40-63 \mu \mathrm{M})$ for column chromatography and silica gel $60 \mathrm{~F}_{254}$ for TLC were supplied by Merck Korea Ltd.

Insect Material The dried centipede, S. subspinipes, was purchased from a market of traditional Asian medicine in Daejeon, Korea.

Extraction and Isolation of Compounds $1-\mathbf{3}$ The dried bodies $(280 \mathrm{~g})$ of centipedes were extracted twice with $\mathrm{MeOH}$ for $2 \mathrm{~d}$. After filtration, the methanol solvent was evaporated to give a residue $(40 \mathrm{~g})$. The $\mathrm{MeOH}$ extracts (40 g) were suspended in water and partitioned with $n$-hexane and $\mathrm{CHCl}_{3}$. The $\mathrm{CHCl}_{3}$-soluble phase $(700 \mathrm{mg})$ was subjected to silica gel chromatography (230-400 mesh, Merck), eluting with a gradient of $\mathrm{CHCl}_{3}-\mathrm{MeOH}(100: 1-$ $0: 100, \mathrm{v} / \mathrm{v})$ to give 11 fractions from the first column. The active fraction (Fr. 5, $460 \mathrm{mg}$ ) was subjected to silica gel column chromatography (230 - 400 mesh, Merck) using a gra- 
dient of $\mathrm{CHCl}_{3}-\mathrm{MeOH}(100: 1-0: 100, \mathrm{v} / \mathrm{v})$ to give 16 fractions (Fr. 5-1-16). Among them, the active fractions (Fr. 5-8, $189 \mathrm{mg}$ ) were subjected to reverse-phase column chromatography (Lichroprep RP-18, 40-63 $\mu \mathrm{M}$, Merck), eluting with $80 \%$ aqueous $\mathrm{MeOH}$ to yield 14 fractions (Fr. 5-8-1-14). The active fractions (Fr. 5-8-3-5) were rechromatographed using reverse-phase column chromatography (Lichroprep RP-18, 40-63 $\mu \mathrm{M}$, Merck), eluting with $75 \%$ aqueous $\mathrm{MeOH}$ to yield 5 fractions. Finally, the active fraction (Fr. 3, 4) was purified with $\mathrm{MeOH}-\mathrm{H}_{2} \mathrm{O}(3: 1, \mathrm{v} / \mathrm{v})$ by preparative TLC (RP C-18) to obtain compound 1 (39 mg). Compound 1 (3,8-dihydroxyquinoline, $\mathrm{C}_{9} \mathrm{H}_{7} \mathrm{NO}_{2}$ ): EI-MS $m / z \quad 161[\mathrm{M}]^{+}$, IR (KBr) $v_{\max } 3400 \mathrm{~cm}^{-1}$, UV (MeOH) $\lambda_{\max } 208,252$, $335 \mathrm{~nm},{ }^{1} \mathrm{H}-\left(\mathrm{CD}_{3} \mathrm{OD}, 500 \mathrm{MHz}\right)$ and ${ }^{13} \mathrm{C}-\mathrm{NMR}\left(\mathrm{CD}_{3} \mathrm{OD}\right.$, $125 \mathrm{MHz}$ ) data were in accordance with reported data. ${ }^{3)}$

The active fraction (Fr. 1, $14 \mathrm{mg}$ ) from the first column was purified by preparative TLC (Silica gel $60 \mathrm{~F}_{254}$, Merck) with $\mathrm{CHCl}_{3}-\mathrm{MeOH}(100: 1, \mathrm{v} / \mathrm{v})$ to obtain compound 2 (3 mg). Compound 2 (2,4-di-tert-butylphenol, $\mathrm{C}_{14} \mathrm{H}_{22} \mathrm{O}$ ): EIMS $m / z 206[\mathrm{M}]^{+},{ }^{1} \mathrm{H}-\left(\mathrm{CD}_{3} \mathrm{OD}, 500 \mathrm{MHz}\right)$, and ${ }^{13} \mathrm{C}-\mathrm{NMR}$ $\left(\mathrm{CD}_{3} \mathrm{OD}, 125 \mathrm{MHz}\right)$ data were in accordance with reported data. ${ }^{12-14)}$

The active fraction (Fr. 6, $40 \mathrm{mg}$ ) from the first column was subjected to preparative TLC (Silica gel $60 \mathrm{~F}_{254}$, Merck) with $\mathrm{CHCl}_{3}-\mathrm{MeOH}(20: 1, \mathrm{v} / \mathrm{v})$ to give 4 fractions (Fr. 6-14). Finally, the active fraction (Fr. 6-2, $25 \mathrm{mg}$ ) was purified by preparative TLC (RP-18 $\mathrm{F}_{254 \mathrm{~S}}$, Merck) with $\mathrm{MeOH}-\mathrm{H}_{2} \mathrm{O}$ $(55: 45, \mathrm{v} / \mathrm{v})$ to obtain compound $3(6 \mathrm{mg})$. Compound 3 (2,8-dihydroxy-3,4-dimethoxyquinoline, $\mathrm{C}_{11} \mathrm{H}_{11} \mathrm{NO}_{4}$ ): EI-MS $m / z: 221(82)[\mathrm{M}]^{+}, \mathrm{UV} \lambda_{\max }(\mathrm{MeOH}) 212,255,284 \mathrm{~nm},{ }^{1} \mathrm{H}-$ NMR (CD $\left.{ }_{3} \mathrm{OD}, 500 \mathrm{MHz}\right): \delta 7.33(1 \mathrm{H}, \mathrm{d}, J=8.0 \mathrm{~Hz}, \mathrm{H}-5)$, $7.05(1 \mathrm{H}, \mathrm{d}, J=8.0 \mathrm{~Hz}, \mathrm{H}-6), 6.93(1 \mathrm{H}, \mathrm{t}, J=8.0 \mathrm{~Hz}, \mathrm{H}-7)$, $4.22(3 \mathrm{H}), 3.88(3 \mathrm{H})$, and ${ }^{13} \mathrm{C}-\mathrm{NMR}\left(\mathrm{CD}_{3} \mathrm{OD}, 125 \mathrm{MHz}\right): \delta$ 163.0 (C-2), 155.6 (C-8), 145.2 (C-4), 136.5 (C-8a), 125.6 (C-6), 123.9 (C-3), 119.6 (C-4a), 114.7 (C-5), 114.5 (C-7), $61.4\left(-\mathrm{OCH}_{3}\right), 61.2\left(-\mathrm{OCH}_{3}\right)$.

TBARS Assay The LDL oxidation was determined spectrophotometrically by measuring the amount of TBARS. $\left.{ }^{15}\right)$ The LDL $(120 \mu \mathrm{g} / \mathrm{ml})$ in PBS buffer (pH 7.4) was mixed with $10 \mu \mathrm{M}$ of $\mathrm{CuSO}_{4}$ and test sample for $4 \mathrm{~h}$ at $37^{\circ} \mathrm{C}$. After incubation, $1 \mathrm{ml}$ of $20 \%(\mathrm{w} / \mathrm{v})$ trichloroacetic acid was added followed by addition of $1 \mathrm{ml}$ of $0.67 \%(\mathrm{w} / \mathrm{v})$ thiobarbituric acid to the postincubation mixture. The mixture was heated at $100{ }^{\circ} \mathrm{C}$ for $15 \mathrm{~min}$ and then cooled. After centrifugation at $1500 \times \boldsymbol{g}$ for $15 \mathrm{~min}$ to remove the precipitated proteins, absorbance of the supernatant was measured at $540 \mathrm{~nm}$. The concentration of TBARS was expressed as equivalents of 1,1,3,3-tetraethoxypropane that was used as a standard. The inhibition ratio (\%) was calculated using the following equation:

inhibition ratio $(\%)=[(\mathrm{A}-\mathrm{A} 1) / \mathrm{A}] \times 100$

where $\mathrm{A}$ is the absorbance of the control and A1 is the absorbance of the sample.

AAPH-Mediated LDL Oxidation Human plasma LDL (120 $\mu \mathrm{g}$ protein $/ \mathrm{ml})$ was oxidized in $10 \mathrm{~mm}$ PBS buffer $(\mathrm{pH}$ 7.4) with $4 \mathrm{~mm}$ AAPH (a free radical generator that thermally decomposes to aqueous peroxy free radicals) at $37^{\circ} \mathrm{C}$ for $4 \mathrm{~h}$ and then the reaction was stopped by addition of $1 \mathrm{~mm}$ EDTA. ${ }^{16)}$ In this experiment, oxidation was carried out in the presence of sample. After the incubation, the extent of LDL- oxidation was measured by TBARS assay.

SIN-1-Mediated LDL Oxidation Human plasma LDL $(120 \mu \mathrm{g}$ protein $/ \mathrm{ml})$ was oxidized in $10 \mathrm{~mm}$ PBS buffer $(\mathrm{pH}$ 7.4) with $1 \mathrm{~mm}$ SIN-1 (a peroxy nitrite generator) at $37^{\circ} \mathrm{C}$ for $4 \mathrm{~h}$ and then the reaction was stopped by addition of $1 \mathrm{~mm}$ EDTA. ${ }^{17)}$ In this experiment, oxidation was carried out in the presence of sample. After the incubation, the extent of LDLoxidation was measured by TBARS assay.

Conjugated Diene Formation The formation of conjugated dienes was measured by monitoring of the absorbance at $234 \mathrm{~nm}^{18)}$ using an UV-VIS spectrophotometer (Hewlett Packard model 8453, Agilent Technologies, Germany). Briefly, $3 \mathrm{ml}$ of an LDL solution $(100 \mu \mathrm{g} / \mathrm{ml})$ in PBS was incubated with $5 \mu \mathrm{M}$ of $\mathrm{CuSO}_{4}$ at $37^{\circ} \mathrm{C}$ in the presence or absence of test sample, following which the absorbance at $234 \mathrm{~nm}$ was measured every $10 \mathrm{~min}$. The plot of absorbance against time produces three phases: (a) a lag phase, (b) a propagation phase, and (c) a decomposition phase. The lag time (the extent to which the compounds protected LDL from oxidation was reflected by prolongation of the lag phase compared to that of control) was measured as the intercept between the baseline and the tangent of the absorbance curve during the propagation phase.

Relative Electrophoretic Mobility (REM) of LDL The REM of native or oxidized LDL was detected by agarose gel electrophoresis. ${ }^{19)}$ The LDL $(120 \mu \mathrm{g} / \mathrm{ml})$ in PBS buffer $(\mathrm{pH}$ 7.4) was mixed with $10 \mu \mathrm{M}$ of $\mathrm{CuSO}_{4}$ and the compounds for $12 \mathrm{~h}$ at $37^{\circ} \mathrm{C}$. Thereafter, sample was loaded onto $0.7 \%$ agarose gel and electorphoresed in TAE buffer ( $40 \mathrm{~mm}$ Tris, $40 \mathrm{~mm}$ acetic acid, and $1 \mathrm{~mm}$ EDTA). After electrophoresis, the gel was dried and stained with Coomassie brilliant blue R250. REM was defined as the ratio of the distances migrated from the origin by ox-LDL $v s$. native LDL.

Electrophoresis of ApoB-100 Fragmentation The inhibition of the oxidative process of compounds $\mathbf{1}-\mathbf{3}$ was evaluated also by studying the fragmentation of apoB-100 through electrophoretic analysis. ${ }^{20)}$ The LDL $(120 \mu \mathrm{g} / \mathrm{ml})$ in PBS buffer (pH 7.4) was mixed with $10 \mu \mathrm{M}$ of $\mathrm{CuSO}_{4}$ and test compound for $4 \mathrm{~h}$ at $37^{\circ} \mathrm{C}$. The denatured ox-LDL solution was then applied to SDS-PAGE (4\%). After the electrophoresis, the gel was stained with Coomassie brilliant blue R250 and subjected to densitometric scanning using a Bio Rad Model GS-800 with Bio Rad Quantity One-4.4.0 software. The areas of the bands of the apoB-100 are expressed as absorbance units per millimeter.

Radical DPPH Scavenging Activity The radical DPPH scavenging activity was measured according to the procedure described by Hatano et al. ${ }^{21)}$ In brief, freshly made radical DPPH solution ( $2 \mathrm{ml}$, final conc. $100 \mu \mathrm{M}$ ) was added to $1 \mathrm{ml}$ each of compounds $\mathbf{1}-\mathbf{3}$ and probucol. The absorbance of DPPH radical remaining was measured at $517 \mathrm{~nm}$ against a blank of pure methanol including only DPPH radical for 20 min using a UV-visible spectrophotometer at room temperature. The radical DPPH scavenging capacity was calculated from the difference in absorbance with sample and probucol and expressed as percent DPPH radical remaining, according to the following equation: \% DPPH remaining $=100 \times($ absorbance of sample/absorbance of control $)$.

Metal Chelating Activity The effects of compounds $1-\mathbf{3}$ on metal chelating were measured by the shift of maximum absorbance. Compounds $\mathbf{1}-\mathbf{3}(100 \mu \mathrm{M})$ were mixed 
with $50 \mu \mathrm{M}$ of $\mathrm{CuSO}_{4}$ in PBS buffer ( $\mathrm{pH} 7.4$ ) and the UV spectra were measured between 200 and $400 \mathrm{~nm}$ either in the presence or absence of compound. ${ }^{22)}$

\section{RESULTS AND DISCUSSION}

As shown in the extraction and isolation procedures, the methanol and acetone extracts obtained exhibited significant antioxidant activity against LDL-oxidation. Subsequently, bioassay-guided fractionation using an LDL-antioxidant assay led to the isolation of the two known compounds $\mathbf{1}$ and $\mathbf{2}$ and a new compound $\mathbf{3}$ (Fig. 1). Compounds $\mathbf{1}$ and $\mathbf{2}$ were determined to be 3,8-dihydroxyquinoline and 2,4-di-tertbutylphenol, respectively, by comparing their physicochemical and spectroscopic data with that reported in the literature. ${ }^{3,12-14)}$ Compound $\mathbf{3}$ has a molecular formula of $\mathrm{C}_{11} \mathrm{H}_{11} \mathrm{NO}_{4}$ by HR-EI-MS [M] ${ }^{+}$at $m / z$ 221.0670, Calcd 221.0688. The IR revealed an absorption band at $3371 \mathrm{~cm}^{-1}$ $(\mathrm{OH})$ and the UV spectrum exhibited $\lambda_{\max }$ at 212, 255, and $284 \mathrm{~nm}(\mathrm{MeOH})$. The ${ }^{1} \mathrm{H}-\mathrm{NMR}$ spectrum showed signals due to two methoxy $(\delta 3.88,4.22)$ groups and three methane protons $(\delta 6.93,7.05,7.33)$. The positions of two hydroxyl and two methoxy groups were determined by HMBC correlations and NOE experiments.

Compounds $\mathbf{1}-\mathbf{3}$ were assayed for antioxidant activity by various assay methods, such as TBARS assay, conjugated diene formation, REM, and fragmentation of apoB-100 on copper-mediated LDL-oxidation. Also, compounds 1-3 were tested for their radical DPPH scavenging activity and metal chelating activity to confirm the mechanism responsible for the antioxidant activity. Compounds $\mathbf{1}-\mathbf{3}$ showed antioxidant activities against LDL-oxidation with $\mathrm{IC}_{50}$ values of 2.6, 8.2, and $63.0 \mu \mathrm{M}$, respectively, in the TBARS assay. A known LDL-antioxidant, probucol, ${ }^{23)}$ was used as a positive control $\left(\mathrm{IC}_{50}=3.1 \mu \mathrm{M}\right)$. Under AAPH-mediated oxidation, compounds $\mathbf{1}-\mathbf{3}$ showed LDL-antioxidant activities with $\mathrm{IC}_{50}$ values of $3.9,9.9$, and $71.8 \mu \mathrm{M}$, respectively (probucol, $\mathrm{IC}_{50}=2.8 \mu \mathrm{M}$ ). Subsequently, under SIN-1-mediated oxidation, compounds $\mathbf{1}-\mathbf{3}$ at $5.0 \mu \mathrm{m}$ exhibited LDL-antioxidant activities, with inhibition rates of $70 \%, 52 \%$, and $29 \%$, respectively.

Oxidation of the LDL was determined by measuring the conjugated diene formation at $234 \mathrm{~nm}$ and typical effects of compounds $\mathbf{1}-\mathbf{3}$ are shown in Fig. 2. The LDL (120 $\mu \mathrm{g}$ protein/ml) in PBS buffer ( $\mathrm{pH} 7.4,10 \mathrm{~mm}$ ) was incubated with $5 \mu \mathrm{M} \mathrm{CuSO}_{4}$ alone to have a lag time of $80 \mathrm{~min}$. When treated with $3.0 \mu \mathrm{M}$ of compounds $\mathbf{1}-\mathbf{3}$, the lag phase of LDL oxidation was retarded to 112,137 , and $97 \mathrm{~min}$, respectively, whereas, probucol extended the lag time to $157 \mathrm{~min}$. Thus, at the same concentration, compounds $\mathbf{1} \mathbf{- 3}$ inhibited less the formation of conjugated diene formation during $\mathrm{Cu}^{2+}$-induced LDL oxidation than did probucol.

The effects of compounds $\mathbf{1}-\mathbf{3}$ on $\mathrm{Cu}^{2+}$-mediated oxidation of LDL were detected by the REM, another parameter that is affected by LDL oxidation, as shown in Fig. 3. The LDL was incubated with $5 \mu \mathrm{M} \mathrm{CuSO}_{4}$ for $12 \mathrm{~h}$ to induce the oxidation of LDL (lane 2). The REM of LDL in compounds 1-3 was reduced in a dose dependent manner. When treated with 20 and $5 \mu \mathrm{M}$ of compound 1 (lanes 3, 4), LDL oxidation was protected to almost the same level, 90\%, compared to that of oxidized LDL (lane 2). Compound 2 at 20 and $5 \mu \mathrm{M}$

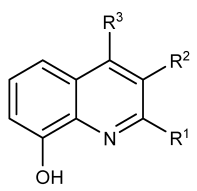

$1 R^{1}=R^{3}=H_{1} R^{2}=O H$ $3 \mathrm{R}^{1}=\mathrm{OH}, \mathrm{R}^{2}=\mathrm{R}^{3}=\mathrm{OMe}$

Fig. 1. Structures of Compounds $\mathbf{1}-\mathbf{3}$ Isolated from Scolopendra subspinip

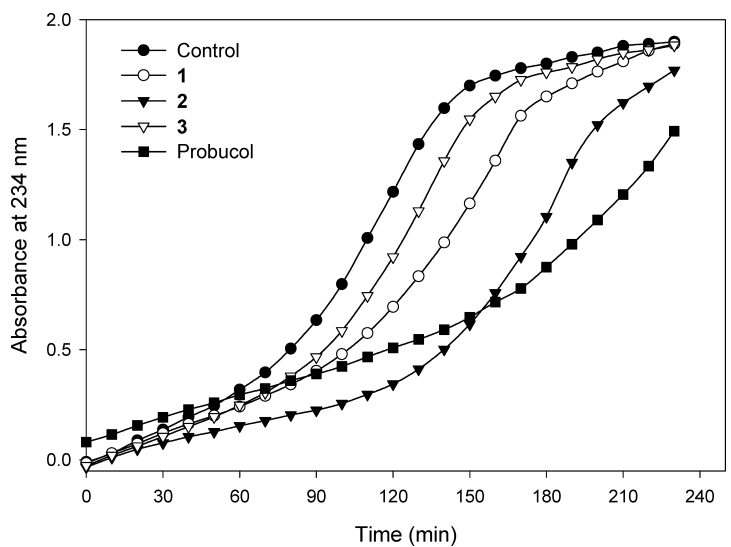

Fig. 2. Effects of Compounds $\mathbf{1}-\mathbf{3}$ on the Generation of Conjugated Diene

LDL $(120 \mu \mathrm{g} / \mathrm{ml})$ in PBS, at $\mathrm{pH} 7.4$, was incubated with $5 \mu \mathrm{M} \mathrm{CuSO}_{4}$ at $37^{\circ} \mathrm{C}$ in the presence or absence of $3 \mu \mathrm{M}$ of compounds $1-3$. Conjugated diene formation was measured by determining the absorbance at $234 \mathrm{~nm}$ every $10 \mathrm{~min}$ for $4 \mathrm{~h}$. Probucol was used as a reference antioxidant. Values shown are those of a representative experiment.

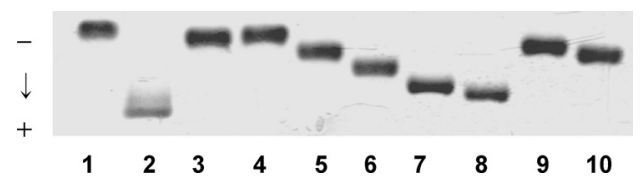

Fig. 3. Effects of Compounds $\mathbf{1}-\mathbf{3}$ on Changes in REM

LDL $\left(120 \mu \mathrm{g} / \mathrm{ml}\right.$ in PBS) was incubated for $12 \mathrm{~h}$ at $37^{\circ} \mathrm{C}$ with $5 \mu \mathrm{M} \mathrm{CuSO}_{4}$ in the absence or presence of compounds $\mathbf{1}-\mathbf{3}$ and probucol. After incubation, approximately $3 \mu \mathrm{g}$ of LDL protein was loaded onto $0.7 \%$ agarose gel for electrophoresis. The gel was dried and stained with Coomassie Brilliant blue R-250. Lane 1: native LDL (absence of $\left.\mathrm{CuSO}_{4}\right)$, lane 2: ox-LDL, lane 3: $1(20 \mu \mathrm{M})$, lane 4: $1(5 \mu \mathrm{M})$, lane 5: $2(20 \mu \mathrm{M})$, lane 6: 2 $(5 \mu \mathrm{M})$, lane $7: 3(20 \mu \mathrm{M})$, lane 8: $3(5 \mu \mathrm{M})$, lane 9: probucol $(20 \mu \mathrm{M})$, lane 10: probucol $(5 \mu \mathrm{M})$.

(lanes 5,6) showed 71\% and 54\% inhibition of LDL-oxidation, respectively. Compound 3 at 20 and $5 \mu \mathrm{M}$ (lanes 7, 8) inhibited LDL oxidation by $31 \%$ and $20 \%$, respectively. Probucol, the positive control, inhibited the oxidation of LDL by $77 \%$ (at $20 \mu \mathrm{M}$, lane 9) and $66 \%$ (at $5 \mu \mathrm{M}$, lane 10 ).

Oxidative inhibition of compounds $\mathbf{1}-\mathbf{3}$ was evaluated by fragmentation of apoB-100 through an electrophoretic method. When LDL $(120 \mu \mathrm{g} / \mathrm{ml}$ in PBS) was incubated with $\mathrm{CuSO}_{4}$ alone, the band of apoB-100 completely disappeared. On the other hand, in the presence of 20 and $5 \mu \mathrm{M}$ of compound 1 , the percentage of remaining apoB-100 was $96 \%$ and $93 \%$, respectively. In the presence of 20 and $5 \mu \mathrm{M}$ of compound $\mathbf{2}$, the percentage of remaining apoB-100 against intact apoB-100 of native LDL was $92 \%$ and $88 \%$, respectively. At the same concentrations of compound $\mathbf{3}$, the fragmentation of apoB-100 was inhibited by $75 \%$ and $57 \%$, respectively. The percentage of remaining apoB-100 bands in the presence of 20 and $5 \mu \mathrm{M}$ of probucol was $88 \%$ and $85 \%$, 
Table 1. Antioxidant Effects of $\mathbf{1}-\mathbf{3}$ on $\mathrm{Cu}^{2+}$-Mediated Oxidation and ApoB-100 Fragmentation in $\mathrm{LDL}^{a)}$

\begin{tabular}{lc}
\hline \hline Compound $(\mu \mathrm{M})$ & Area $(\mathrm{AU} / \mathrm{mm})^{b)}$ \\
\hline Native LDL & $22.15 \pm 0.21$ \\
Ox-LDL & 0 \\
$\mathbf{1}(20)$ & $21.27 \pm 0.20$ \\
$\mathbf{1}(5)$ & $20.51 \pm 0.25$ \\
$\mathbf{2}(20)$ & $20.45 \pm 0.19$ \\
$\mathbf{2}(5)$ & $19.54 \pm 0.20$ \\
$\mathbf{3}(20)$ & $16.55 \pm 0.28$ \\
$\mathbf{3}(5)$ & $12.67 \pm 0.36$ \\
Probucol $(20)$ & $19.49 \pm 0.22$ \\
Probucol $(5)$ & $18.78 \pm 0.25$
\end{tabular}

a) $\mathrm{LDL}\left(120 \mu \mathrm{g} / \mathrm{ml}\right.$ in PBS) was incubated for $12 \mathrm{~h}$ at $37^{\circ} \mathrm{C}$ with $5 \mu \mathrm{M} \mathrm{CuSO}_{4}$ in the absence or presence of compounds $\mathbf{1}-\mathbf{3}$, and probucol. Then, approximately $2.0 \mu \mathrm{g}$ of LDL protein was applied to SDS-PAGE $(4 \%)$. The gel was stained with Coomassie Brilliant blue R250 and subjected to densitometric scanning using a Bio Rad Model GS-800 with Bio Rad Quantity One-4.4.0 software to compare the residual apoB-100 band intensity. $b$ ) Areas of the bands of the apoB-100 are expressed as the mean of absorbance units per millimeter \pm S.D. $(n=3)$.

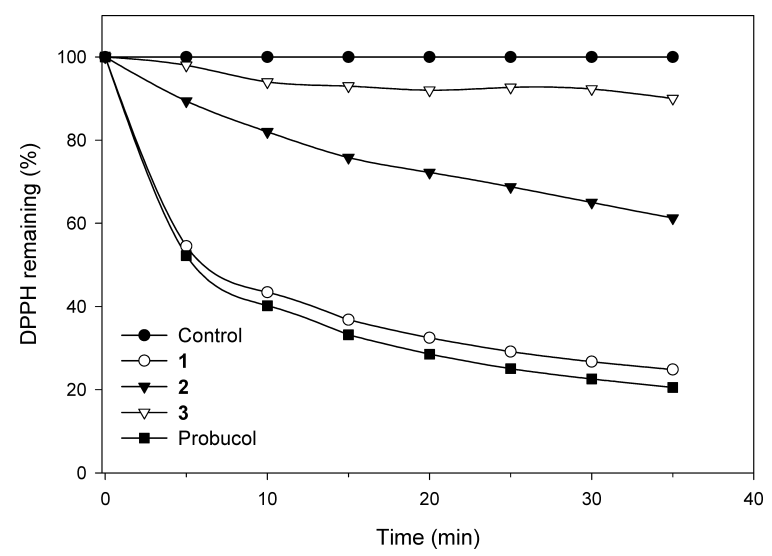

Fig. 4. Effects of Compounds $\mathbf{1}-\mathbf{3}$ on Radical DPPH Scavenging

Compounds 1-3 $(100 \mu \mathrm{M})$ were incubated with $100 \mu \mathrm{M}$ of DPPH in methanol at room temperature for $35 \mathrm{~min}$. The absorbance at $517 \mathrm{~nm}$ of each compound solution was measured. The antiradical activity is expressed as the percentage of remaining $\mathrm{DPPH}$

respectively (Table 1$)$.

Compounds $\mathbf{1}-\mathbf{3}$ were tested for their radical DPPH scavenging activity potential (Fig. 4) and the effects on $\mathrm{Cu}^{2+}$ chelate formation (Fig. 5), whether chelation or oxidation. In general, DPPH is known as a very stable free radical and widely used for evaluation of antioxidant activities. ${ }^{24)}$ Compounds $\mathbf{1}-\mathbf{3}$ were tested for their radical DPPH scavenging activity at $100 \mu \mathrm{M}$. The activities of compounds $\mathbf{1}-\mathbf{3}$ were measured as decolorizing activity following the trapping of the unpaired electron of DPPH. After $35 \mathrm{~min}, 36 \%$ and $75 \%$ of the DPPH radicals, respectively, remained in the presence of compounds $\mathbf{1}$ and $\mathbf{2}$, whereas $93 \%$ remained for compound 3 having a methoxy group (Fig. 4). In the test of $\mathrm{Cu}^{2+}$-chelating capacity, the maximum absorbance of compound $\mathbf{1}$ was changed from 248 to $265 \mathrm{~nm}$ by the formation of metal-compound 1 chelate (Fig. 5). However, a change in the maximum absorbance of compounds $\mathbf{2}$ and $\mathbf{3}$ was not (data not shown). Therefore, compound $\mathbf{1}$ was proven to exhibit dual antioxidant activities, as radical scavenger and $\mathrm{Cu}^{2+}$-chelator.

In the study of the antioxidant properties of quinolines and phenol, the antioxidant activity of quinoline $\mathbf{1}$ with two aromatic $\mathrm{OH}$ groups at positions 3 and 8 was relatively high against LDL-oxidation, whereas the $O$-substituted quinoline

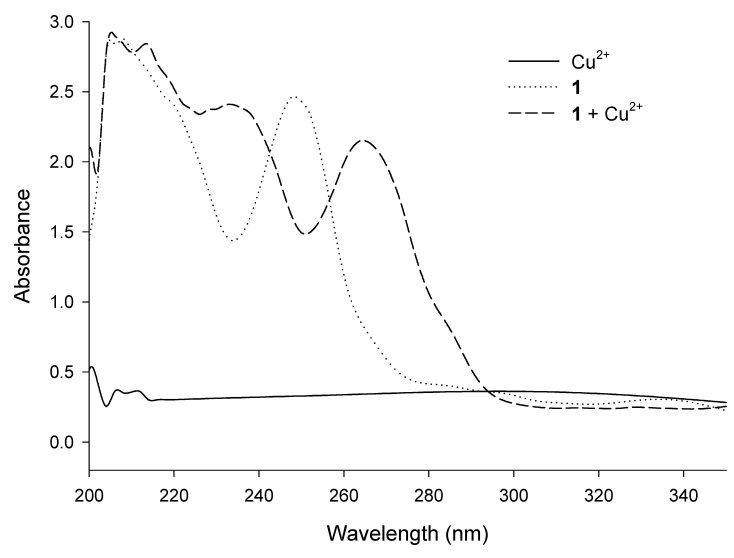

Fig. 5. Effect of Compound 1 on Metal Chelation

Compound $1(50 \mu \mathrm{M})$ was incubated with or without $100 \mu \mathrm{M}$ of $\mathrm{CuSO}_{4}$ in $\mathrm{PBS}(\mathrm{pH}$ 7.4) and the spectra were recorded on a UV-VIS spectrophotometer.

3 at positions 3 and 4 showed only negligibly weak antioxidant activity. According to the results of Pinchuk and Lichtenberg, ${ }^{25}$ antioxidants are reducing agents that reduce transition metals or interact with free radicals to result in the formation of antioxidant-derived free radicals. Also, Ziouzenkova et al. $^{26)}$ reported that copper ions are bound to high as well as to low affinity sites to generate lipid peroxyl radicals (LOO·), which can be effectively inhibited by $\alpha$ tocopherol. It has also been demonstrated that 2,6-di-tertbutylphenol is more reactive toward a radical source to afford 2,6-di-tert-butylphenoxy radical in an inhibition of free radical reaction. ${ }^{27)}$ The antioxidant activities of $\mathbf{1}-\mathbf{3}$ against LDL-oxidation were consistent with the results of their scavenging abilities of the DPPH radical.

In conclusion, 3,8-dihydroxyquinoline (1), 2,4-di-tertbutyl-phenol (2), and 2,8-dihydroxy-3,4-dimethoxyquinoline (3) were isolated by bioassay-guided fractionation from $S$. subspinipes. Furthermore, we demonstrated the antioxidant activities using various LDL-oxidation tools (e.g., TBARS assay, conjugated diene formation, the REM of ox-LDL, apoB-100 fragmentation, radical DPPH scavenging activity, and copper chelating activity). Further studies on an in vivo efficacy test for cholesterol-lowering and anti-atherogenic activities are currently underway.

Acknowledgements This research was supported by a grant (FGC0100413) from the Ministry of Science and Technology, Korea and a grant (BioGreen 21 Project) from the Rural Development Administration, Korea.

\section{REFERENCES AND NOTES}

1) "Dictionary of Chinese Crude Drugs," Ching Su New Medical College, Shanghai Scientific Technologic, ed., 1997, pp. 2473-2475.

2) Pemberton R. W., J. Ethnopharmacol., 65, 207-216 (1999).

3) Moon S. S., Cho N. S., Shin J. H., Seo Y. W., Lee C. O., Choi S. U., J. Nat. Prod., 59, 777-779 (1996).

4) Kim K. T., Kim H. J., Park K. B., Cho K. S., J. Korean Chem. Soc., 42, 236-239 (1998).

5) Noda N., Yashiki Y., Nakatani T., Miyahara K., Du X. M., Chem. Pharm. Bull., 49, 930-931 (2001).

6) Park D. S., Yoon M. A., Xu M. Z., Yu H., Kim J. R., Jeong T. S., Park H. Y., Kor. J. Pharmacogn., 35, 233-238 (2004).

7) Daniel S., J. Biol. Chem., 272, 20963-20966 (1997).

8) Akira T., Yan H., Maria F. L. V., Atherosclerosis, 154, 79—86 (2001). 
9) Konovalova G. G., Lisina M. O., Tikhaze A. K., Lankin V. Z., B. Exp. Biol. Med., 2, 143-146 (2003).

10) Jialal I., Devaraj S., Clin. Chem., 42, 498-506 (1996).

11) Parthasarathy S., Santanam N., Ramachandran S., Meilhac O. J. Lipid Res., 40, 2143-2157 (1999).

12) Pouchert C. J., Behnke J., "The Aldrich Library of ${ }^{13} \mathrm{C}$ - and ${ }^{1} \mathrm{H}-\mathrm{NMR}$ Spectra," Edition 1, Vol. 2, Aldrich Chemical Company, Inc., 1993, p. 267.

13) Pouchert C. J., "The Aldrich Library of FT-IR Spectra Vapor Phase," Edition 1, Vol. 1, Aldrich Chemical Company, Inc., 1985, p. 1088B.

14) Kamitori Y., Hojo M., Masuda R., Izumi T., Tsukamoto S., J. Org. Chem., 49, 4161-4165 (1984).

15) Wallin B., Rosengren B., Shertzer H. G., Camejo G., Anal. Biochem., 208, 10-15 (1993).

16) Devaraj S., Li D. J., Vazquez M., Jialal I., Free Radic. Biol. Med., 26, 1064-1068 (1999).

17) Gugliucci A., Menini T., Life Sci., 71, 693-705 (2002).

18) Khursheed P. N., Enrique B., Charles S. L., Atherosclerosis, 152, 89-
95 (2000).

19) Reid V. C., Mitchinson M. J., Atherosclerosis, 98, 17-24 (1993).

20) Matsukawa N., Nariyama Y., Hashimoto R., Kojo S., Bioorg. Med. Chem., 11, 4009-4013 (2003).

21) Hatano T., Edamatsu R., Mori A., Fujita Y., Yasuhara T., Yoshida T., Okuda T., Chem. Pharm. Bull., 37, 2016-2021 (1989).

22) Sergejew T., Forgiarini P., Schnebli H. P., Brit. J. Haematol., 110, 985-992 (2000).

23) Barnhart R. L., Busch S. L., Jackson R. L., J. Lipid Res., 30, 17031710 (1989).

24) Bridges A. B., Scott N. A., Belch J. J., Atherosclerosis, 89, 263-265 (1991).

25) Pinchuk I., Lichtenberg D., Prog. Lipid Res., 41, 279-314 (2002) and reference cited therein.

26) Ziouzenkova O., Sevanian A., Abuja P. M., Ramos P., Esterbauer H., Free Rad. Bio. Med., 24, 607-623 (1998).

27) Mahony L. R., DaRooge M. A., J. Am. Chem. Soc., 89, 5619-5629 (1967). 